\title{
A a tualidade da obra de Fernando C. Prestes Motta
}

\begin{abstract}
A educação moderna convencional muito raramente se preocupa com o desenvolvimento da pessoa. Opta, normalmente e com a cumplicidade dos pais ansiosos por filhos bem-sucedidos na "vida", pelo desenvolvimento funcional ou profissional, exacerbando a angústia do adolescente. As instituições educacionais e, de modo especial, a universidade, nasceram como um espaço no qual o mestre formava seus discípulos através da convivência diária. Esse espaço tornou-se uma grande burocracia impessoal em que a convivência é meramente funcional. Busca-se formar boas engrenagens, no melhor dos casos, e não pessoas adultas, maduras individual e socialmente. (Fernando Cláudio Prestes Motta)
\end{abstract}

A trajetória intelectual de Fernando Motta é das mais originais entre as últimas gerações do meio acadêmico brasileiro. Graduou-se em Administração de Empresas pela Escola de Administração de Empresas de São Paulo, da Fundação Getúlio Vargas, em 1967. Nesse mesmo ano ingressou, mediante concurso público, na carreira docente, no posto de instrutor. Naquela instituição fez carreira brilhante, chegando a professor-titular em 1980. Na EAESP/FGV, obteve os títulos de mestre em 1969, com a dissertação intitulada Racionalismo capitalista e evolução da empresa brasileira, e de doutor em 1980, com a tese Burocracia e autogestão: a proposta de Proudhon.

Ingressou no Departamento de Administração Escolar e Economia da Educação da Feusp em outubro de 1979 e lecionou durante anos na graduação e na pós-graduação, tendo orientado vários mestres e doutores, e participado ativamente da criação da atual linha de pesquisa Cultura, Organização e Educação. Em 1985, realizou concurso para professor-associado e, em 1991, tornou-se professor-titular por intermédio de outro concurso de provas e títulos.

Concluíram suas dissertações de mestrado, sob a orientação de Fernando Motta, os seguintes alunos: Robinson J anes (Educação popular e burocracia: antagonismos existentes), Luis Carlos Toledo (Propaganda política: fator de massificação e legitimação sociais: visão tradicional e novas abordagens). Orientou também cinco teses de doutorado, a saber: Relações de poder na escola pública do Ensino Fundamental: uma radiografia à luz de Weber e Bourdieu (Magali de Castro); 0 brasão e o logotipo: um estudo das novas universidades na cidade de São Paulo (Cleide Rita Silvério de Almeida); Cultura, poder e legitimação na organização escolar: um estudo de caso (Lucília Bechara Sanches); Da ideologia do desenvolvimento à ideologia da globalização: a educação como estratégia do Banco Mundial para "alívio" da pobreza (Roberto Leher); Identidade e autonomia da escola pública: 0 projeto das escolas- padrão (Sérgio Fiker). 
A originalidade mencionada acima decorre do modo pelo qual ele desenvolveu sua crítica à organização burocrática, construída por meio de uma formação realizada no próprio campo da administração e da leitura de autores de tradição libertária.

Seu primeiro livro, Teoria geral da administração: uma introdução, publicado em 1974, conheceu vinte e duas edições sem alteração. A vigésima terceira foi lançada em 2002, tendo sido atualizada com a colaboração de Isabella F.G.de Vasconcelos. Publicou doze livros, freqüentou, entre outras, as páginas da Revista de Administração de Empresas (RAE), da EAESP/FGV, assinando três dezenas de artigos e várias resenhas. Infelizmente é impossível resgatar toda a riqueza da obra de Fernando Motta nos limites deste espaço. No entanto, gostaríamos de destacar seu livro Organização e poder: empresa, Estado e escola, fruto de sua tese de livre- docência, defendida em 1985, na Faculdade de Educação da USP.

Nessa obra, o autor amplia e aprofunda sua análise acerca das organizações complexas mostrando a interconexão entre dominação e exploração no mundo contemporâneo, recorrendo aos clássicos da sociologia das organizações e a autores heterodoxos libertários, até hoje pouco citados no meio acadêmico. Apresenta uma consciência epistemológica radicalmente crítica e se posiciona com clareza, desmistificando a pretensa neutralidade metodológica e axiológica das teorias da administração.

0 artigo que aqui republicamos foi originalmente divulgado na então Revista da Faculdade de Educação (à qual Educação e Pesquisa dá continuidade), em seu volume 10, número 2, de 1984. Trata-se de um texto que já antecipa muitas das posições do autor em sua busca por desvendar os mecanismos de dominação e de exploração, incluindo o campo da educação, sem perder de vista as práticas que a eles se contrapõem, e que teve grande repercussão na época. Sua atualidade se deve à lucidez de um estudioso atento aos dilaceramentos da sociedade em que vivemos, para os quais buscava, nas teorias e práticas libertárias, o antídoto.

Fernando Motta aposentou-se na USP em 1997, após quase dezoito anos trabalhando conosco. 0 objetivo deste tributo à sua memória é chamar a atenção dos leitores para a atualidade e importância de sua obra, despertando naqueles que não o conheceram 0 interesse em lê-la. É tarefa fecunda para todos os envolvidos com a Educação.

Afrânio Mendes Catani Doris Accioly e Silva Lúcia E. N. Barreto Bruno 